\title{
A study of knowledge and attitudes towards plagiarism among medical faculty \& postgraduate students
}

\author{
Dhaval Jugabhai Parmar ${ }^{1}$, Rashmika Dhaval Parmar ${ }^{2 *}$ \\ ${ }^{\mathbf{1}}$ Professor and Head, ${ }^{\mathbf{2}}$ Associate Professor, ${ }^{\mathbf{1}}$ Dept. of Forensic Medicine, ${ }^{\mathbf{2}}$ Dept. of Microbiology, ${ }^{\mathbf{1 - 2}}$ M. P. Shah Government Medical \\ College, Jamnagar, Gujarat.
}

\section{*Corresponding Author: Rashmika Dhaval Parmar}

Email: dhavalrash@yahoo.com

\begin{abstract}
Introduction: Plagiarism is misappropriation of another person's ideas. But, surprisingly there seems to be significant underreporting. An informal discussion on plagiarism with faculties and Post Graduate students revealed that most of them were not sensitized for it. Hence, Study attempts to explore the status of their knowledge and attitude about plagiarism to build awareness and improve their attitudes to minimize plagiarism.

Materials and Methods: Present cross sectional study was conducted at GMC, Bhavnagar (Gujarat) by convenient sampling of Study group in to faculty (Group A) and Post graduate medical students (group B) while using two (1.To analyze knowledge regarding plagiarism 2.To analyze Attitude toward plagiarism) set of structured, validated instruments. Results of responses collected anonymously from both the groups were appropriately analyzed by statistical methods to yield scientific inferences.

Results: Analysis of knowledge of both faculty and students exhibits prevailing disbeliefs about plagiarism (Direct word to word copypaste is considered as plagiarism by faculty $(65 \%)$ and P.G. students $(70 \%)$ although $35 \%$ faculty and $38 \%$ P.G. students believe plagiarism can be avoided by replacing the words). Their knowledge is deficient about forms \& ways of plagiarism as well about secondary citations. Responses revealed that only direct copying of phrases is regarded as dishonest deed. Faculty \& P.G students on one hand showed moderate attitude toward plagiarism which mean they perceive plagiarism in the community is fraud. But on other hand both faculty

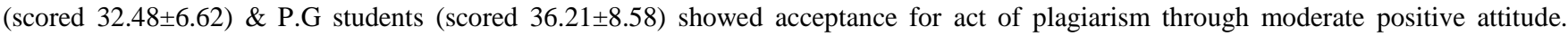
Negative attitude of both groups was moderate displaying their tolerance for plagiarism in the community.

Conclusions: Present Study revealed that Medical faculty and P.G. students have misunderstandings about plagiarism while their increasing active flaw towards such behaviour due to Internet is likely to increase plagiarism frequency. Thus strong regulations \& reinforcements are gravely needed to prevent impending spread \& normalization of plagiarism.
\end{abstract}

Keywords: Plagiarism, Knowledge, Attitude.

\section{Introduction}

One of the main motivations for this study was based on personal experience. While evaluating a dissertation submitted for Post graduate MD degree, it was noticed that not only most of the texts of thesis were replication of textbooks \& Journals without appropriate citation but also many references were fake without any citation in text. Surprisingly, despite reporting of non-acceptance of dissertation, the applicant gain access to final postgraduate exam as same was accepted by other examiners. It is evident that poor assessment processes nurture misconduct and plagiarism. ${ }^{1}$ Such obvious instance of plagiarism leading to devaluation of postgraduate master degree in Medical science is matter of significant concern and was felt disastrous and painful. When the plagiarism issue informally discussed with many faculty and Post Graduate (PG) students, surprisingly most of them were not sensitized for it.

Plagiarism is appropriation of another person's ideas, processes, results or words without giving appropriate credits and usually claiming them to be one's own. ${ }^{2}$ Thus plagiarism is dishonest act of cheating or fraud. ${ }^{3}$

Although computers make plagiarism easier to perform, they also make it easier to detect and quantify it. ${ }^{4}$ surprisingly there seems to be significant underreporting of dishonesty and misconduct. ${ }^{5}$ It is apt to recognize plagiarism to set appropriate prevalence of academic integrity. Ignorance towards plagiarism may lower morals of students drifting them to choose plagiarism instead of honesty \& hard work which in turn is educationally counterproductive threat for academic community. ${ }^{6}$

This study is an attempt to explore level of understanding and attitude of Medical Post graduate students \& Faculty about concepts of plagiarism. This will possibly draw the attention of faculty \& students towards need to minimize plagiarism, to build awareness \& improve attitudes.

\section{Materials and Methods}

Present cross sectional study was undertaken at Government Medical College Bhavnagar, Gujarat, after obtaining approval from Institutional Review board. Study group was divided in to two groups using convenient sampling, faculty (Group A) and Post graduate medical students (group B). Study was conducted using two set of structured, validated instruments.

\section{To analyze Knowledge regarding plagiarism ${ }^{7}$}

Fourteen validated questions on knowledge based on variety of behaviours \& 15 different scenarios of plagiarism, that might or might not constitute plagiarism were given to participants with answer option "yes" or "no." Percentage of correct responses calculated for these 29 items determined 
existing knowledge of plagiarism among both groups. Result of responses of P.G. students and faculty were analyzed using unpaired ' $t$ ' test to compare if difference in response is significant or not. $\mathrm{P}$ values $<0.05$ were considered as significant difference.

\section{To analyze Attitude toward Plagiarism ${ }^{8}$}

Responses to 29 validated statements measuring three attitudinal aspects toward plagiarism (positive or negative attitude and subjective norms) were graded on Likert scale: Grades 1 - strongly disagree, 2 - disagree, 3 - neither agree nor disagree, 4 - agree and 5 - strongly agree. Accordingly, scores designated to each answer and were calculated by summing.

12 out of 29 statements related to procedures that participants do by themselves with score range 12-60 were reflecting positive attitude of approval or acceptance to plagiarism. Hence, low score range 12-28 suggesting low tolerance to plagiarism is preferred.

7 out of 29 statements related to procedures done by others or prevalent in society with score range 7-35 were reflecting negative attitude of condemnation of dishonesty. Hence, high score range 27-35 suggesting no tolerance of plagiarism is preferred.

10 out of 29 statements related to perceived extent of acceptance of plagiarism with score range 10-50 were reflecting subjective norms in society. Hence, low score range 10-23 suggesting annoyance for plagiarism is preferred.

Finally, minimal and maximal possible scores of each feature and ranges were divided in three equal parts representing low, moderate and high score scales so as to calculate scores for both groups as mean score \pm SD for each attitudinal factor.

Results were collected anonymously from both groups by circulating study instrument, giving them time to fill their responses \& return it. Participants' consent to take part in the study was inferred by their completion of the study instrument.

\section{Results and Discussion}

\section{Analysis of Knowledge regarding plagiarism}

Responses of Table 1, item 1 as copying words from another source without acknowledgement is noticeably observed as plagiarism by most faculty $(65 \%)$ and P.G. students $(70 \%)$. Although same get obscured when their extent of misunderstanding is evaluated further. Thus, clear plagiarism is not recognized by $35 \%$ of faculty and $30 \%$ of P.G. students.

Table 1: Definitions of plagiarism ${ }^{7}$

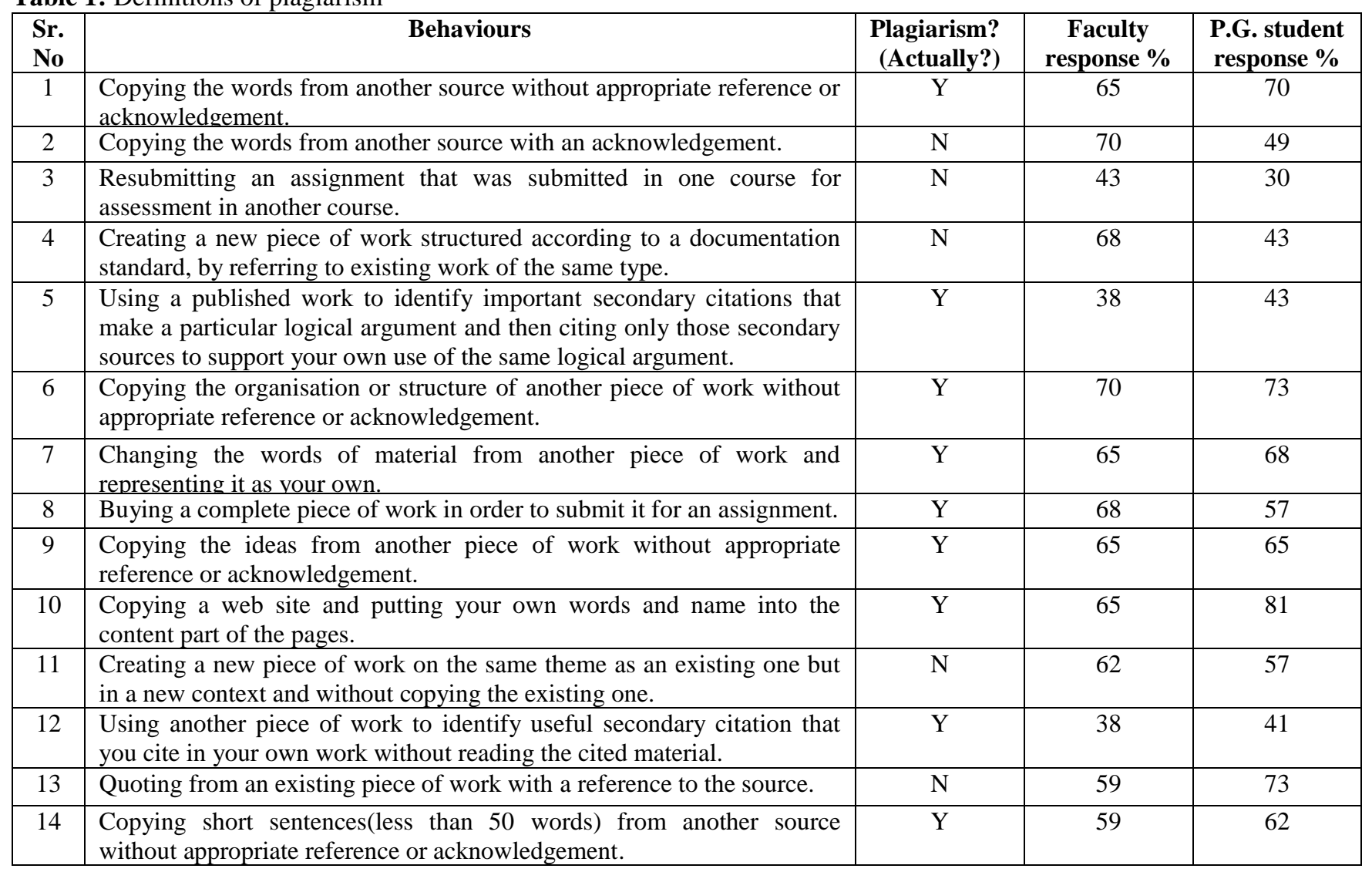

Responses of Table 1, items 5, 6 and 7, are revealing puzzlement about use of materials from other sources, 
(62\% faculty and 59\% P.G. students) suggest faculties surpass P.G. students in confusions about secondary citations. While, $41 \%$ faculty and $27 \%$ P.G. students failed to recognize that quoting with acknowledgements (Table 1, item 13) is normal citation practice. Although, 35\% faculty and $38 \%$ P.G. students have wrong impression that replacing the words (Table 1, item 7) can avoid plagiarism.

On one hand $57 \%$ faculty and $70 \%$ P.G. students consider resubmission of an assignment as dishonest conduct or plagiarism (Table 1, Item 3) but surprisingly $30 \%$ faculty and $51 \%$ P.G. students misjudge that copying the words from another source with an acknowledgement is plagiarism (Table 1, item 2) .
Responses of P.G. students and faculty in Table 1 were analyzed using unpaired ' $t$ ' test. $P$ value $0.37(<0.05)$ suggest difference in response is not significant.

Different plagiarism scenarios are presented to see patterns of beliefs better than that with definition-based instruments. Such scenarios based instrument provide background to dissociate responder from their position so as to fittingly apply different views or roles as per their own pattern of beliefs. ${ }^{9}$ Perusals of responses to scenarios (Table 2) uncover the false beliefs of both faculty and students about different forms of plagiarism, as at some occasions they take on plagiarism as tolerable.

Table 2: Scenarios of plagiarism ${ }^{8}$

\begin{tabular}{|c|c|c|c|c|}
\hline $\begin{array}{l}\text { Sr. } \\
\text { No }\end{array}$ & Scenarios & Plagiarism? & $\begin{array}{c}\text { Faculty response } \\
\%\end{array}$ & $\begin{array}{l}\text { P.G. student } \\
\text { response \% }\end{array}$ \\
\hline 1 & $\begin{array}{l}\text { A student is working on an assignment that is worth a significant } \\
\text { proportion of the marks for a course. They conduct a web search and } \\
\text { discover several obscure web pages containing useful material. They copy } \\
\text { sections of the material from the different pages directly into their } \\
\text { assignment without citing the source. They then add additional original } \\
\text { material linking the copied material into a whole and submit the work as } \\
\text { entirely their own. }\end{array}$ & $\mathrm{Y}$ & 70 & 73 \\
\hline 2 & $\begin{array}{l}\text { A student copies the installation CD for a commercial software package } \\
\text { from their employer that is only licensed for use on the business premises. } \\
\text { They then install the software on their home computer so they can use it } \\
\text { to do work that relates to their courses at University. }\end{array}$ & $\mathrm{N}$ & 46 & 46 \\
\hline 3 & $\begin{array}{l}\text { A student submits unchanged their own originally created work, which } \\
\text { they have previously used for another course, for assessment in yet } \\
\text { another course. }\end{array}$ & $\mathrm{Y}$ & 27 & 41 \\
\hline 4 & $\begin{array}{l}\text { A student is working on an assignment that is worth a significant } \\
\text { proportion of the marks for a course. While reading a book in the library } \\
\text { they discover a page that contains a useful block of material. They copy } \\
\text { the material into their assignment answer without citing the source and } \\
\text { submit the work as entirely their own. }\end{array}$ & $\mathrm{Y}$ & 57 & 68 \\
\hline 5 & $\begin{array}{l}\text { A student copies the installation CD for the latest cool game from a friend } \\
\text { and installs it on their computer in order to play the game. }\end{array}$ & $\mathrm{N}$ & 62 & 59 \\
\hline 6 & $\begin{array}{l}\text { A student, who is a fan of a TV series, carefully videotapes each episode } \\
\text { and creates a personal library of the tapes which they share with friends } \\
\text { and retain for their own enjoyment over a number of years. }\end{array}$ & $\mathrm{N}$ & 54 & 65 \\
\hline 7 & $\begin{array}{l}\text { An employee preparing a report for internal use at their company } \\
\text { discovers a similar report online using a search engine and uses at the } \\
\text { basis of their own report, paraphrasing it and introducing additional } \\
\text { material specific to their own situation. }\end{array}$ & $\mathrm{Y}$ & 65 & 51 \\
\hline 8 & $\begin{array}{l}\text { A student submits unchanged their own originally created work, which } \\
\text { they have previously prepared as part of their employment, for assessment } \\
\text { in a course. }\end{array}$ & $\mathrm{Y}$ & 49 & 49 \\
\hline 9 & $\begin{array}{l}\text { A student who is a fan of a particular musical group and who owns many } \\
\text { of their CDs borrows an import CD from a friend that is not available for } \\
\text { purchase and burns a copy for their own use. }\end{array}$ & $\mathrm{N}$ & 43 & 62 \\
\hline 10 & $\begin{array}{l}\text { A student and a staff member work together on a particular problem. } \\
\text { Together they work out an interesting solution that includes a significant } \\
\text { contribution from the student. The staff member submits the solution as a } \\
\text { paper without the students name listed as an author and without any } \\
\text { acknowledgement of the student's contribution. }\end{array}$ & $\mathrm{N}$ & 35 & 35 \\
\hline 11 & $\begin{array}{l}\text { A student, having received a good mark for a piece of assessed work, sells } \\
\text { the work to an online paper mill that they know on-sells the work to other } \\
\text { students. }\end{array}$ & $\mathrm{Y}$ & 38 & 49 \\
\hline
\end{tabular}




\begin{tabular}{|c|l|c|c|c|}
\hline 12 & $\begin{array}{l}\text { A student is working on an assignment that is worth a significant } \\
\text { proportion of the marks for a course. While studying in the library they } \\
\text { discover a final draft of another student's work for that assignment. They } \\
\text { copy the material into their assignment directly and submit the work as } \\
\text { entirelv their own and without anv mention of the other students name. }\end{array}$ & $\mathrm{Y}$ & 70 \\
\hline 13 & $\begin{array}{l}\text { A student who is a fan of particular musical group and who owns many } \\
\text { of their CDs converts the contents to computer files which they can then } \\
\text { sort and play in different orders while working at their computer. }\end{array}$ & $\mathrm{N}$ & 58 \\
\hline 14 & $\begin{array}{l}\text { An employee copies the installation CD for a commercial software } \\
\text { package from a friend and installs it on a work computer in order to } \\
\text { complete an important piece of work that will generate considerable } \\
\text { business for the company and likely result in a bonus to them personally. }\end{array}$ & $\mathrm{N}$ & 27 \\
\hline 15 & $\begin{array}{l}\text { A student uses an existing novel as the basis of a short satirical allegory. } \\
\text { The resulting work acknowledges the origin of the allegory and only } \\
\text { includes short quotes or directly copied material. The student submits the } \\
\text { work for assessment in a course as their own original work. }\end{array}$ & $\mathrm{N}$ & 35 \\
\hline
\end{tabular}

Table - 2, item1, 4, 11 and 12 are obvious plagiarism scenarios recognizable by most faculty and P.G. students, but uncertainty regarding plagiarism is palpable in $62 \%$ faculty and $51 \%$ P.G. students in scenario (Table 2, item 11) of students selling his own work to an online paper mill. Evidentially confusion is prevailing in use of electronic material like installation of software from a CD for working (Table 2 item 2), is misunderstood as plagiarism by $54 \%$ of faculty and P.G. students. While in contrast scenarios of copying CD of games, TV episodes or of music for entertainment (Table 2 items 5, 6 and 9) which are not plagiarism are misinterpreted as plagiarism by more than third of faculty and P G. students.

Scenarios of resubmission of own work for another course (Table 2 item 3 ) though a clear plagiarism case is identified by only $27 \%$ of faculty and $41 \%$ of P.G. students, whereas similar scenario of resubmission of previously used assignment in employment for another course (Table 2 item 8 ) is regarded as plagiarism by $49 \%$ of faculty and P.G. students. Scenario of student using quotes from novel with acknowledgement is not plagiarism even though $49 \%$ of faculty and $68 \%$ of P.G. students erratically identify it as plagiarism.
Responses of P.G. students and faculty in Table 2 were analyzed using unpaired ' $\mathrm{t}$ ' test. $\mathrm{P}$ value $0.281(<0.05)$ suggest difference in response is not significant.

Perusal of responses of Table 1 and 2 are suggestive that vagueness about concept $\&$ different manners of plagiarism is prominent amongst students which gets confounded at some occurrences where plagiarism is unobjectionable if done soundly. ${ }^{10}$ Customarily, indirect copying is more tolerable than direct copying of phrases \& thus routinely Faculty and P.G. students regard plagiarism as inconsequential trivial happening. ${ }^{11}$

\section{Analysis of Attitudes toward Plagiarism}

Moderate attitude of faculty \& P.G students for plagiarism is proclaimed through results of three attitudinal factors (Table 3) as well their moderate Subjective norms can be sensed through views depicting that plagiarism is inappropriate in the community and is fraud. But quite the opposite both faculty (scored $32.48 \pm 6.62$ ) \& P.G students (scored 36.21 \pm 8.58 ) give consent to plagiarism by showing moderate positive attitude. Their view is further enfolded by their moderate negative attitude of lenience for plagiarism in the community.

Table 3: Scores for three attitudinal factors towards plagiarism and reference ranges of low, Moderate and high attitude for each factor

\begin{tabular}{|l|c|l|l|l|}
\hline \multirow{2}{*}{ Attitudinal factor } & \multicolumn{2}{|c|}{ Mean+ SD } & \multicolumn{2}{c|}{ Reference range } \\
\cline { 2 - 4 } & Faculty & P.G. student & \multicolumn{2}{c}{} \\
\hline Positive attitude & & & Low* & $12-28$ \\
& & & Moderate & $29-45$ \\
& $32.48 \pm 6.62$ & $36.21 \pm 8.58$ & High & $46-60$ \\
\hline Negative attitude & & & Low & $7-16$ \\
& & & Moderate & $17-26$ \\
& $21.97 \pm 3.21$ & $22.67 \pm 3.89$ & High* & $27-35$ \\
\hline Subjective norms & & & Low* & $10-23$ \\
& & & Moderate & $24-37$ \\
& $28.62 \pm 4.89$ & $30.18 \pm 6.37$ & High & $38-50$ \\
\hline
\end{tabular}

* Favourable attitude for academic integrity 
Presentations (Table 3) of moderate scores for all three attitudes demonstrate jumble in knowledge \& tumble in attitude towards plagiarism which is likely to topple the ideal standards of academic integrity among faculty \& P.G students. Such paucity of attitude would yield results in performances which prohibit righteous progress of science \& scientific community. ${ }^{12,13,14}$

Furthermore, answers to questionnaire statements presented in Table 4 , are distributed to derive \& discuss attitudes towards plagiarism.

Table 4: Distribution of answers of Attitude toward Plagiarism questionnaire

\begin{tabular}{|c|c|c|c|c|c|c|c|c|c|c|c|}
\hline \multirow{2}{*}{$\begin{array}{l}\text { Sr. } \\
\text { No }\end{array}$} & \multirow[t]{2}{*}{ Statements } & \multicolumn{5}{|c|}{ Faculty $(\mathrm{N}=37) \%$} & \multicolumn{5}{|c|}{ PG. students(N=37)\% } \\
\hline & & 1 & 2 & 3 & 4 & 5 & 1 & 2 & 3 & 4 & 5 \\
\hline \multicolumn{2}{|r|}{ Statements describing positive attitude } & \multicolumn{10}{|c|}{ Responses in \% } \\
\hline 1 & $\begin{array}{l}\text { Sometimes one cannot avoid using other people's words } \\
\text { without citing the source, because there are only so many } \\
\text { ways to describe something }\end{array}$ & 22 & 16 & 6 & 51 & 5 & 16 & 11 & 11 & 43 & 19 \\
\hline 2 & $\begin{array}{l}\text { It is justified to use previous descriptions of a method, } \\
\text { because the method itself remains the same }\end{array}$ & 0 & 16 & 3 & 65 & 16 & 14 & 24 & 22 & 35 & 5 \\
\hline 3 & $\begin{array}{l}\text { Self-plagiarism is not punishable because it is not harmful } \\
\text { (one cannot steal from oneself) }\end{array}$ & 3 & 24 & 38 & 24 & 11 & 8 & 14 & 14 & 35 & 30 \\
\hline 4 & $\begin{array}{l}\text { Plagiarized parts of a paper may be ignored if the paper is of } \\
\text { great scientific value }\end{array}$ & 22 & 32 & 14 & 32 & 0 & 5 & 35 & 16 & 19 & 24 \\
\hline 5 & $\begin{array}{l}\text { Self-plagiarism should not be punishable in the same way as } \\
\text { plagiarism is }\end{array}$ & 11 & 24 & 30 & 30 & 5 & 11 & 16 & 19 & 22 & 32 \\
\hline 6 & $\begin{array}{l}\text { Young researchers who are just learning the ropes should } \\
\text { receive milder punishment for plagiarism }\end{array}$ & 8 & 43 & 32 & 16 & 0 & 22 & 32 & 30 & 8 & 8 \\
\hline 7 & $\begin{array}{l}\text { If one cannot write well in a foreign language (eg, English), } \\
\text { it is justified to copy parts of a similar paper already } \\
\text { published in that language }\end{array}$ & 19 & 32 & 30 & 14 & 0 & 16 & 22 & 32 & 16 & 14 \\
\hline 8 & I could not write a scientific paper without plagiarizing & 41 & 35 & 10 & 14 & 0 & 35 & 14 & 35 & 11 & 5 \\
\hline 9 & Short deadlines give me the right to plagiarize a bit & 22 & 30 & 27 & 16 & 5 & 19 & 14 & 46 & 11 & 11 \\
\hline 10 & $\begin{array}{l}\text { When I do not know what to write, I translate a part of a } \\
\text { paper from a foreign language }\end{array}$ & 14 & 41 & 24 & 19 & 0 & 11 & 22 & 22 & 24 & 22 \\
\hline 11 & $\begin{array}{l}\text { It is justified to use one's own previously published work } \\
\text { without providing citation in order to complete the current } \\
\text { work }\end{array}$ & 19 & 49 & 11 & 22 & 0 & 27 & 24 & 11 & 32 & 5 \\
\hline 12 & $\begin{array}{l}\text { If a colleague of mine allows me to copy from her/his paper, } \\
\text { I'm NOT doing anything bad, because I have his/her } \\
\text { permission }\end{array}$ & 8 & 32 & 32 & 22 & 5 & 16 & 24 & 11 & 32 & 16 \\
\hline \multicolumn{12}{|c|}{ Statements describing negative attitude } \\
\hline 13 & Plagiarists do not belong in the scientific community & 19 & 35 & 11 & 30 & 5 & 19 & 22 & 22 & 24 & 14 \\
\hline 14 & $\begin{array}{l}\text { The names of the authors who plagiarize should be disclosed } \\
\text { to the scientific community }\end{array}$ & 3 & 14 & 5 & 49 & 30 & 5 & 16 & 27 & 30 & 22 \\
\hline 15 & $\begin{array}{l}\text { In times of moral and ethical decline, it is important to } \\
\text { discuss issues like plagiarism and self-plagiarism }\end{array}$ & 3 & 8 & 5 & 51 & 32 & 3 & 5 & 14 & 32 & 46 \\
\hline 16 & Plagiarizing is as bad as stealing an exam & 5 & 14 & 8 & 51 & 22 & 0 & 11 & 14 & 41 & 35 \\
\hline 17 & Plagiarism impoverishes the investigative spirit & 14 & 8 & 16 & 46 & 16 & 22 & 14 & 22 & 27 & 16 \\
\hline 18 & A plagiarized paper does no harm science & 38 & 27 & 14 & 14 & 8 & 24 & 30 & 24 & 5 & 16 \\
\hline 19 & $\begin{array}{l}\text { Since plagiarism is taking other people's words rather than } \\
\text { tangible assets; it should NOT be considered as a serious } \\
\text { offense }\end{array}$ & 22 & 59 & 19 & 0 & 0 & 16 & 41 & 24 & 11 & 8 \\
\hline \multicolumn{12}{|c|}{ Statements describing subjective norms } \\
\hline 20 & Authors say they do NOT plagiarize, when in fact they do & 8 & 8 & 14 & 51 & 16 & 8 & 8 & 41 & 27 & 16 \\
\hline 21 & Those who say they have never plagiarized are lying & 0 & 11 & 38 & 38 & 11 & 0 & 5 & 43 & 30 & 22 \\
\hline 22 & $\begin{array}{l}\text { Sometimes I'm tempted to plagiarize, because everyone else } \\
\text { is doing it (students, researchers, physicians) }\end{array}$ & 11 & 14 & 35 & 27 & 14 & 16 & 14 & 19 & 30 & 22 \\
\hline 23 & I keep plagiarizing because I haven’t been caught yet & 14 & 62 & 11 & 0 & 11 & 11 & 30 & 38 & 5 & 16 \\
\hline 24 & I work (study) in a plagiarism-free environment & 22 & 24 & 11 & 38 & 5 & 16 & 30 & 24 & 22 & 8 \\
\hline 25 & Plagiarism is not a big deal & 22 & 65 & 8 & 3 & 0 & 22 & 35 & 27 & 8 & 8 \\
\hline
\end{tabular}




\begin{tabular}{|l|l|c|c|c|c|c|c|c|c|c|c|}
26 & $\begin{array}{l}\text { Sometimes I copy a sentence or two just to become inspired } \\
\text { for further writing }\end{array}$ & 8 & 30 & 14 & 49 & 0 & 14 & 14 & 19 & 49 & 5 \\
\hline 27 & $\begin{array}{l}\text { I don't feel guilty for copying verbatim a sentence or two } \\
\text { from my previous papers }\end{array}$ & 11 & 14 & 8 & 68 & 0 & 19 & 16 & 14 & 43 & 8 \\
\hline 28 & $\begin{array}{l}\text { Plagiarism is justified if I currently have more important } \\
\text { obligations or tasks to do }\end{array}$ & 11 & 32 & 43 & 14 & 0 & 11 & 22 & 43 & 19 & 5 \\
\hline 29 & Sometimes, it is necessary to plagiarize & 16 & 38 & 11 & 35 & 0 & 14 & 41 & 19 & 16 & 11 \\
\hline
\end{tabular}

Likert scale, grades $1=$ strongly disagree, $2=$ disagree, $3=$ neither agree nor disagree, $4=$ agree and $5=$ strongly agree (Results in percentage \%).

\section{Statements describing positive attitude}

Outcome is contrasting that on one hand faculty $(56 \%) \&$ P.G students (62\%) concur that they would mask the lack of writing skills (statement 1) though on other hand faculty $(76 \%)$ and $49 \%$ of P.G. students do differ to accept that they could not write scientific paper without plagiarizing (statement 8). Likewise more than $60 \%$ of faculty \& P.G students presume self plagiarism as not detrimental (statements 2, 3, and 5). Faculty show clear disagreement toward plagiarism when excuses of scientific value, good writing or short time (statements 4, 7, 9, 10 and 11) are put but P.G students have mixed opinions or are considering plagiarism acceptable in such situations. More than half of faculty $(51 \%)$ \& P.G students $(54 \%)$ disagree with any excuse to plagiarize on account of being learner (statement 6). An issue of copying with permission (statement 12) is considered bad by at least $40 \%$ of faculty whereas, it's agreeable to P.G students (48\%).

\section{Statements describing negative attitude}

Nearly three quarter of faculty (73\%) \& P.G students (76\%) criticize plagiarism as equivalent to cheating in an exam (statement 16) while Faculty (62\%) \& P.G students (43\%) assert that plagiarism also deprives probing spirit (statement 17). Correspondingly, $70 \%$ of them advocate discussing about tolerance levels for plagiarism (statement 15) \& publicizing of perpetrators of plagiarism (statement 14). In spite of this much leniency for plagiarism is exhibited as any direct harm to science is not perceived as risky (statement 18) which in turn fix their mind set of considering plagiarism as quite ordinary than offence like misuse of material goods (statement 19) Ambiguity is exposed in attitude also if plagiarists is fit to assimilate in scientific community (statement 13).

\section{Statements describing subjective norms}

Answers suggest that Faculty (67\%) believe plagiarism exist (statements 20) while P.G students are unclear about it. Half of faculty (49\%) \& P.G students (52\%) know deceitfulness of people despite plagiarizing (statements 21) but many (Faculty (38\%) \& P.G students (43\%)) choose neutral attitude. Faculty and P.G students have agreed and disagreed in equal proportion to embrace plagiarism-free ambiance (statement 24). However, half of them have no regret in copying text from their prior work (statement 27). Both faculty and P.G students have mixed opinions or choose to remain neutral when justifying plagiarism due to some other obligations (statement 28), But they (faculty (54\%) \& P.G students (55\%)) show disagreement about any necessity to plagiarize (statement 29).

It is observable that respondents (faculty and P.G. students) prefer to appear honest by disfavoring plagiarism despite of their participation, since they try to endorse \& defend self plagiarism as well tend to generalize leniency \& positive attitude towards plagiarism in community. Same is consistent with conclusions of Hren et al. displaying noticeable level of Machiavellianism among Croatian students. ${ }^{15}$ Such perceptible disparity between attitude and actions can be clarified with Festinger's Theory of Cognitive Dissonance ${ }^{16,17}$ which explains that psychological discomfort generated due to coexistence of contrasting attitudes \& actions drives person to attempt balance due to their own awareness (Internal conflict). Thus the choice of "moderate" positive and negative response by both faculty and P.G. students is to accomplish balance over their own internal conflicts.

\section{Conclusions}

This study discovered that Medical faculty and P.G. students are much disoriented about concepts of plagiarism $\&$ different ways in which they may plagiarize during scientific writing. Such deficit added with their deprivation from understanding the seriousness of violations due to plagiarism could drag them in to behavior comprising plagiarism. Furthermore, availability of computer \& internet has expanded their active flow towards such behavior which do augment frequency of plagiarism.

Due to limited scope, our study is provisional and merely indicative of the status quo of plagiarism at our institute. There is a need for studies that explore how recognition and understanding of plagiarism is formed and put into practice, how one draw on the words and ideas of others, and how technology is utilized for transition of becoming independent scientific writers.

Medical faculty and P.G. students are appearing to disfavor plagiarism while being tolerant believing it less harmful \& even defending self participation. Thus they show off moderate attitudes towards plagiarism to attain balance over their own internal conflicts of contrasting attitudes \& actions. Righteously there is felt need of stringent regulations \& reinforcements to obstruct impending normalization of plagiarism. 


\section{Acknowledgements}

We wish to thank all participants who gave their time to participate in the study.

\section{Source of Funding: None.}

\section{Conflict of Interest: None.}

\section{Whether you have published this paper other than this journal: No}

\section{References}

1. Carroll, J. (2002). A handbook for deterring plagiarism in higher education. Oxford: Oxford Centre for Staff and Learning Development, Oxford Brookes University.

2. Bilic Zulle L, Frkovic V, Azman J, Turk T, Mladen P. Prevalence of plagiarism among medical students. Croat Med $J$ 2005;56:126-131.

3. Merriam-Webste. Merriam-Webste Online Dictionary. Massachusetts: Merriam-Webster Inc; 2012 [cited Janyary12, 2012]; Available from: http://www.merriam-webster.com.

4. Grover D. Plagiarism and the internet: the use of correlation techniques to detect plagiarism. Computer Law and Security Report. 2003;19:36-8.

5. Tavare A: Managing research misconduct: is anyone getting it right. BMJ 2011, 343:d8212.

6. Walker JR. Copyrights and conversations: intellectual property in the classroom. Computers and Composition.1998;15:24351.

7. Marshall, S. J., \& Garry. How well do students really understand plagiarism? ascilite 2005: Balance, Fidelity, Mobility: maintaining the momentum?. 2005;457-67.

8. Vanja Pupovac1, Lidija Bilic-Zulle1, 2, Martina Mavrinac1, Mladen Petrovecki1,3. Attitudes toward plagiarism among pharmacy and medical biochemistry students - cross-sectional survey study. Biochemia Medica 2010;20(3):30713.http://dx.doi.org/10.11613/BM.2010.039.

9. Wood, J., Longenecker, J., McKinney, J., \& Moore, C. (1988). Ethical attitudes of students and business professionals: A study of moral reasoning. J Business Ethics, 7, 249.257.

10. Anderson, J. (1998). Plagiarism, copyright violation and other thefts of intellectual property. Jefferson, NC: McFarland and Company.5.

11. Park, C. (2003). In other (people's) words: Plagiarism by university students -literature and lessons. Assessment and Evaluation in Higher Education, 28(5):471-88.

12. Bilić-Zulle L, Ažman J, Frk ović V, Petrovečk i M. Is there an effective approach to deterring students from plagiarizing? Sci Eng Ethics. 2008; 14:139-47.

13. Kenny D. Student plagiarism and professional practice. Nurse Educ Today 2007; 27:14-8.

14. Harding TS, Carpenter DD, Finneli CJ, Passow HJ. Does academic dishonesty relate to unethical behavior in professional practice? An exploratory study. Sci Eng Ethics 2004; 10:311-24.

15. Hren D, Vujak lija A, Ivanisević R, Knezević J, Marušić M, Marušić A. Students' moral reasoning, Machiavellianism and socially desirable responding: implications for teaching ethics and research integrity. Med Educ 2006;40:269-77.

16. Festinger, L. (1957). A Theory of Cognitive Dissonance. California: Stanford University Press last accessed on 29 September http://en.wikipedia.org/wiki/Cognitive_dissonance.

17. Festinger, L. (1962). Cognitive dissonance. Scientific American, 207(4), 93-107.

How to cite this article: Parmar DJ, Parmar RD.A study of knowledge and attitudes towards plagiarism among Medical Faculty \& Postgraduate students. Indian $J$ Forensic Community Med 2019; 6(4):255-61. 